\title{
Tidal transport of Pectinaria koreni postlarvae (Annelida: Polychaeta) in the Bay of Seine (eastern English Channel)
}

\author{
Eric Thiébaut ${ }^{1, *}$, Jean-Claude Dauvin ${ }^{2}$, Zixian Wang $^{2}$ \\ ${ }^{1}$ Université P. \& M. Curie - Paris VI, Océanologie biologique, Bât. A, Case 6, 4 Place Jussieu, F-75252 Paris cedex 05, France \\ ${ }^{2}$ Muséum National d'Histoire Naturelle, Laboratoire de Biologie des Invertébrés Marins et Malacologie, CNRS URA 699, \\ 57 rue Cuvier, F-75252 Paris cedex 05, France
}

\begin{abstract}
Recent investigations on the recruitment of marine benthic invertebrates have highlighted the ability of postlarval and juvenile stages to re-enter the water column and undergo a consequent dispersal following primary settlement. In the eastern part of the Bay of Seine (English Channel), abundances of Pectinaria koreni postlarvae within the water column were measured hourly at 1 station over 2 time series of 93 and $92 \mathrm{~h}$ conducted in May 1991 and 1992 to determine the magnitude and frequency of postlarval transport and its dependency on current velocity and bottom shear stress. Postlarval numbers varied strongly with the state of the tide; mean densities were consistently larger, by at least one order of magnitude, during flood than during ebb. Maximum densities were observed with about a $2 \mathrm{~h}$ delay relative to the tidal current speed and bottom shear stress maxima. No diurnal rhythm of migratory activity was observed. The interaction of postlarval drifting and tide generates a net landward transport which could partly reduce the demographic consequences of larval dispersal. This mechanism is proposed to be one of the major processes which explain the spatial and temporal stability of the adult population in a highly advective and dispersive environment. The potential effects of other environmental factors (e.g. wind events) are also discussed
\end{abstract}

KEY WORDS: Postlarval dispersal · Recruitment - Pectinaria koreni English Channel

\section{INTRODUCTION}

Larvae are acknowledged to be the dispersal stage of coastal marine benthic invertebrates at large spatial scales (Scheltema 1986). However, recent work has suggested that postlarval and juvenile transport occur for numerous taxa, including molluscs, crustaceans and polychaetes (Butman 1987, Günther 1992, Armonies 1994). Such a transport may modify juvenile distributions, after primary settlement, at spatial scales from meters to kilometers and result in changes of habitat for entire populations, as was observed for the bivalve Macoma balthica in the Wadden Sea (Beukema \& de Vlas 1989, Armonies \& Hellwig-Armonies 1992). Until now, most of the studies carried out concentrated on

·E-mail: pm@ccr.jussieu.fr the causes of postlarval dispersal (e.g. reaction to predation or competition, response to environmental disturbances, search for suitable areas) and its consequences in terms of population dynamics. In contrast, few of them have correlated this mechanism with hydrodynamical processes. In the Wadden Sea, transport of Macoma balthica thread-drifting postlarvae was related to the state of the tide, such that higher numbers were sampled when the current speed was maximal (Beukema \& de Vlas 1989). Likewise Palmer \& Gust (1985) showed in the North Inlet Estuary (South Carolina, USA) that meiofauna dispersal in the water column depended primarily on the intensity of the friction velocity.

In the eastern part of the Bay of Seine (English Channel), the tubicolous worm Pectinaria koreni is confined to the insular, muddy fine sand Abra alba-Pectinaria koreni community, of which it is one of the most com- 
mon species (Gentil et al. 1986, Thiébaut 1994, E. Thiébaut, L. Cabioch, J. C. Dauvin, C. Retière \& F. Gentil unpubl.). Pectinaria koreni exhibits 2 spawning periods, i.e. in spring and in summer (Irlinger et al. 1991). During their development, which ranges from 11 to 13 d (Lagadeuc \& Retière 1993), larvae can be transported up to at least 30 to 40 nautical miles from the point of origin, depending on tidal residual circulation and wind-induced current (Lagadeuc 1992). Such a dissemination generates a primary settlement of postlarvae on a large area irrespective of the sediment texture (Lambert et al. 1996). Nevertheless Lambert (1991) and Olivier et al. (in press) have shown in flume experiments that Pectinaria koreni postlarvae and juveniles could select the substrate and be transported after primary settlement. The drift-transport is induced by the secretion of a mucus thread which increases drag forces on individuals (Lambert 1991).

From 2 data-sets of hourly planktonic samples collected in May 1991 and 1992 at 1 station located in the eastern part of the Bay of Seine, the aims of the present study were (1) to quantify in situ Pectinaria koreni postlarval abundances in the water column and (2) to determine their short-term fluctuations with respect to environmental factors (i.e. the hydrodynamic regime and the day/night cycle). The results were analysed in terms of postlarval transport, and their possible consequences on recruitment were discussed.

\section{MATERIALS AND METHODS}

Study area. Along the French coasts of the English Channel, the Bay of Seine forms a quadrilateral embayment characterized by a macrotidal hydrodynamic regime (Fig. 1). The tidal range varies between $3.0 \mathrm{~m}$ at neap tide and $7.5 \mathrm{~m}$ at spring tide (Chabert d'Hières 1986). Instantaneous tidal currents are elliptic. Tidal flows are asymmetrical so that flood currents are stronger but shorter in duration than ebb currents (Le Hir \& L'Yavanc 1986). Maximum tidal current speeds range from $0.5 \mathrm{~m} \mathrm{~s}^{-1}$ in the eastern part of the bay to $0.8 \mathrm{~m} \mathrm{~s}^{-1}$ in the middle of the bay (Chabert d'Hières 1986). Benthic communities are distributed in response to hydrodynamical and sedimentary gradients, from a muddy fine sand community in coastal shallow waters to medium sand and sandy gravel communities in offshore waters (Cabioch \& Gentil 1975).

Sampling. Sampling was carried out at Stn F $\left(49^{\circ} 26.60^{\prime} \mathrm{N}, 00^{\circ} 01.30^{\prime} \mathrm{E}\right)$ in shallow waters seaward of the Seine estuary (Fig. 1). Stn F was located at the centre of the Abra alba-Pectinaria koreni muddy fine sand community in the south of the channel entrance to Le Havre harbour. Samples were taken during 1 period of $93 \mathrm{~h}$ on 23-27 May 1991 and 1 period of $92 \mathrm{~h}$

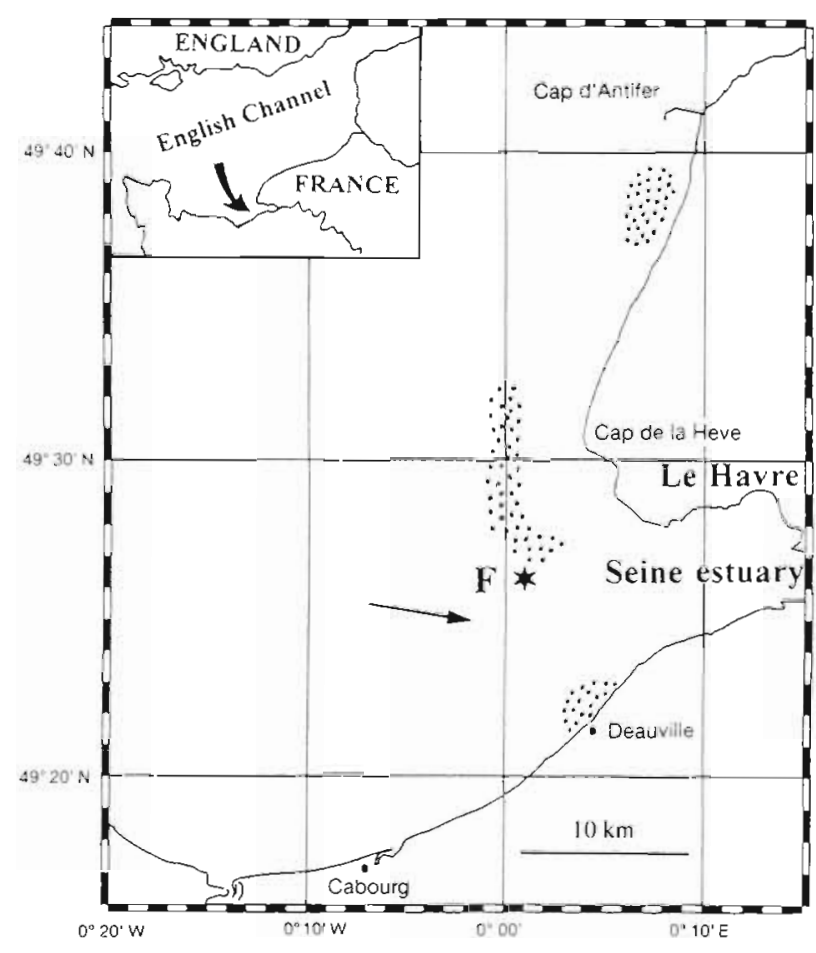

Fig. 1. Study area and location of the sampling station (Stn F) seaward of the Seine estuary. Dotted areas indicate the distribution of Pectinaria koreni adult population (densities $\geq 50$ ind. $\mathrm{m}^{-2}$ ) in March 1991 (from Thiébaut 1994). The arrow indicates the main direction of flood current at Stn F

on 25-29 May 1992. Averaged tidal ranges were 4.6 and $4.5 \mathrm{~m}$ in 1991 and 1992 respectively. P. koreni postlarvae were collected hourly at $2 \mathrm{~m}$ intervals, from $1 \mathrm{~m}$ below the surface to the bottom, using a $10 \mathrm{~cm}$ diameter collection pipe and a volumetric pump (PCM Moineau) delivering a constant flow of $300 \mathrm{l} \mathrm{min} \mathrm{m}^{-1}$. A sample of $0.6 \mathrm{~m}^{3}$ was obtained at each depth over $2 \mathrm{~min}$, sieved through an $80 \mu \mathrm{m}$ mesh net and preserved in $5 \%$ formalin buffered with sodium borate. Current speeds and directions were measured every 2 min by a RCM 8 Aanderaa Current Meter at $2 \mathrm{~m}$ above the bottom. Due to a technical hitch, current measurements were available during only the first $82 \mathrm{~h}$ of the sampling period in 1991.

Data analysis. Metamorphosis of Pectinaria koreni larvae into the aulophore stage (i.e. postlarvae) occurs in the water column (Lagadeuc \& Retière 1993). The aulophore is characterized by a coniform membraneous parchment-like tube. Thread-drifting aulophores which have already had contact with the substrate can be distinguished from planktonic aulophores by the occurrence of sand grains attached to the anterior ends of tubes. The term 'postlarvae' is used for young recruits acquiring morphological adult characteristics (i.e. construction of the sand tube, morphogenesis of 
gills and buccal tentacles) over a period of about $2 \mathrm{wk}$ (Lambert et al. 1996). The term 'juveniles' refers to older recruits. Counts of drifting postlarvae were done after sub-sampling as explained in Thiébaut et al. (1992). Briefly, the sample was diluted to $200 \mathrm{ml}$ with seawater, homogenised, and an aliquot was pipetted into a reticulate Dolfuss receptacle. Approximatively 100 postlarvae were counted per sample to obtain a good estimation of their total abundance. Results were expressed as number of postlarvae $\mathrm{m}^{-3}$.

Averaged current parameters (i.e. speed and direction) were calculated every hour coincident with biological samples. The bottom shear stress $\left(\tau, \mathrm{N} \mathrm{m}^{-2}\right)$ was estimated by the friction velocity $\left(u \cdot, \mathrm{m} \mathrm{s}^{-1}\right)$ as follows (Gross \& Nowell 1983):

$$
u \cdot=(\tau / \rho)^{0.5}
$$

where $\rho$ is the fluid density. Measurements of temperature and salinity during both surveys showed that seawater density near the bottom remained close to $1025.0 \mathrm{~kg} \mathrm{~m}^{-3}$, whatever the tidal stage.

Friction velocity (u*) was determined from the logarithmic von Karman-Prandtl equation (Gross \& Nowell 1983):

$$
u_{(z)}=\frac{u \cdot}{k} \ln \left(\frac{z}{z_{0}}\right)
$$

where $u_{(z)}$ is the velocity at height $z, k$ is von Karman's constant (equal to 0.4 ) and $z_{0}$ is the bed roughness. As no permanent or temporary sediment structure (i.e. ripples and dunes) were observed in the studied area (Auffret \& d'Ozouville 1986), $z_{0}$ was calculated according to Van Rijn (1982)

$$
z_{0}=0.033 k_{\mathrm{s}}
$$

where $k_{s}$, Nikuradse's roughness, is equal to $3 \phi_{i}$ $\phi$ is the sediment mean diameter equal to $196 \mu \mathrm{m}$ at our site (Thiébaut pers. obs.).

The spatio-temporal variations in the distribution of postlarvae were depicted with contour plots using Golden Graphics System software (SURFER).

According to Armonies (1994), 2 assumptions are required to estimate the most likely mode of water column entrance of postlarvae: (1) the postlarval abundance is statistically related to water flow, indicative of passive erosion from the sediment, and (2) the postlarval abundance varies significantly with the day/night cycle, indicative of active behaviour. Different nonparametric and parametric statistical analyses were used to assess which appropriate assumptions were valid. Significant differences $(\alpha=$ 0.05 ) in postlarval abundances with respect to tidal stage and diel cycle were tested using the non-parametric Mann-Whitney U-test (Scherrer 1984). Auto- and cross-correlation analyses (Legendre \& Legendre 1984) were performed to determine the periodicity of depth-averaged postlarval abundance fluctuations and to compare this with bottom shear stress variations. Auto- and cross-correlation coefficients were calculated at $1.0 \mathrm{~h} \mathrm{lag}$ intervals and plotted as a function of lag As homoscedacity of data is important for these analyses, postlarval abundances were previously log-transformed. Confidence intervals of correlation coefficients at $\alpha=0.05$ were calculated using the Bartlett's test (Legendre \& Legendre 1984).

\section{RESULTS}

\section{Hydrodynamics}

During the sampling periods, instantaneous tidal currents varied between 12 and $48 \mathrm{~cm} \mathrm{~s}^{-1}$ in May 1991 and 7 and $43 \mathrm{~cm} \mathrm{~s}^{-1}$ in May 1992, according to the semi-diurnal tidal cycle (Figs. 2 \& 3). Maximum speeds occurred during the first $2 \mathrm{~h}$ of the flood. Minimum
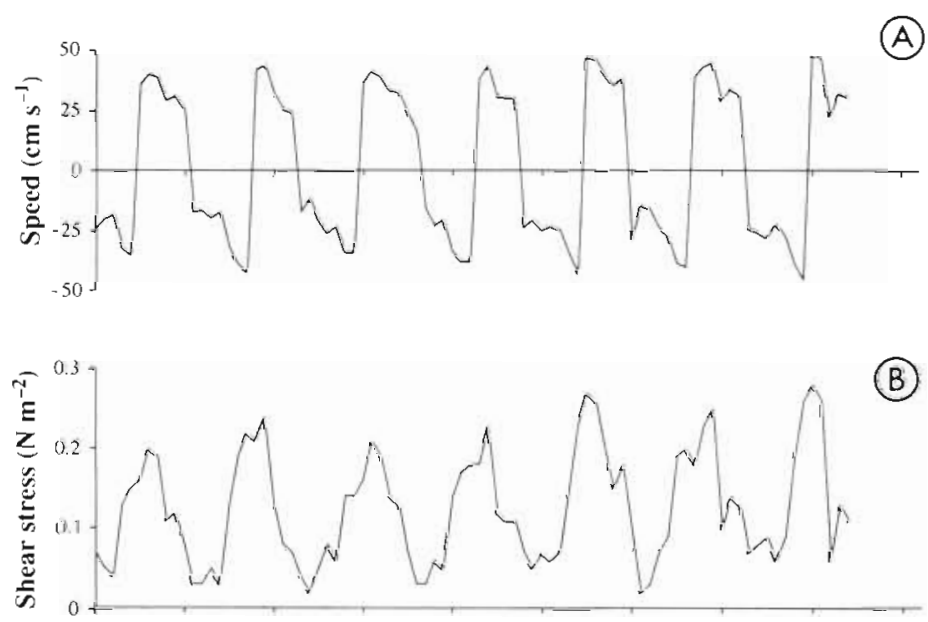

(C)

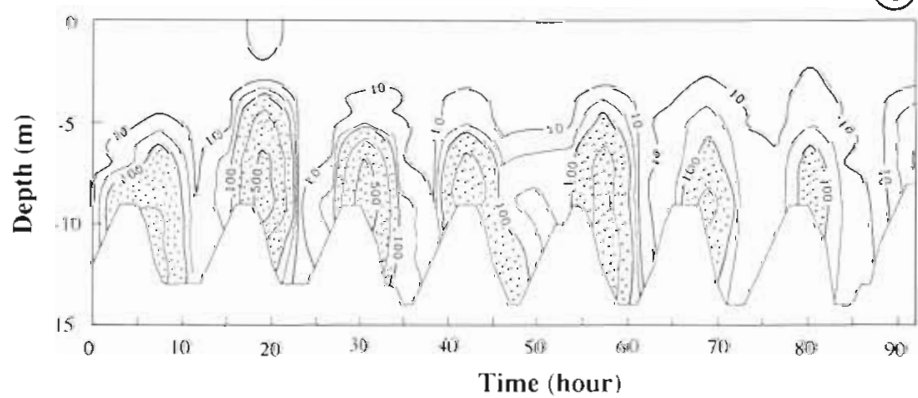

Fig. 2. (A) Short-term evolution of current speed in $\mathrm{cm} \mathrm{s}^{-1},(B)$ estimated bottom shear stress in $\mathrm{N} \mathrm{m}^{-2}$, and (C) postlarval Pectinaria koreni densities in ind. $\mathrm{m}^{-3}$ at Stn $\mathrm{F}$ during the first sampling period, 23-27 May 1991 Dotted area in $\mathrm{C}$ indicates densities $\geq 100$ ind. $\mathrm{m}^{-3}$ 

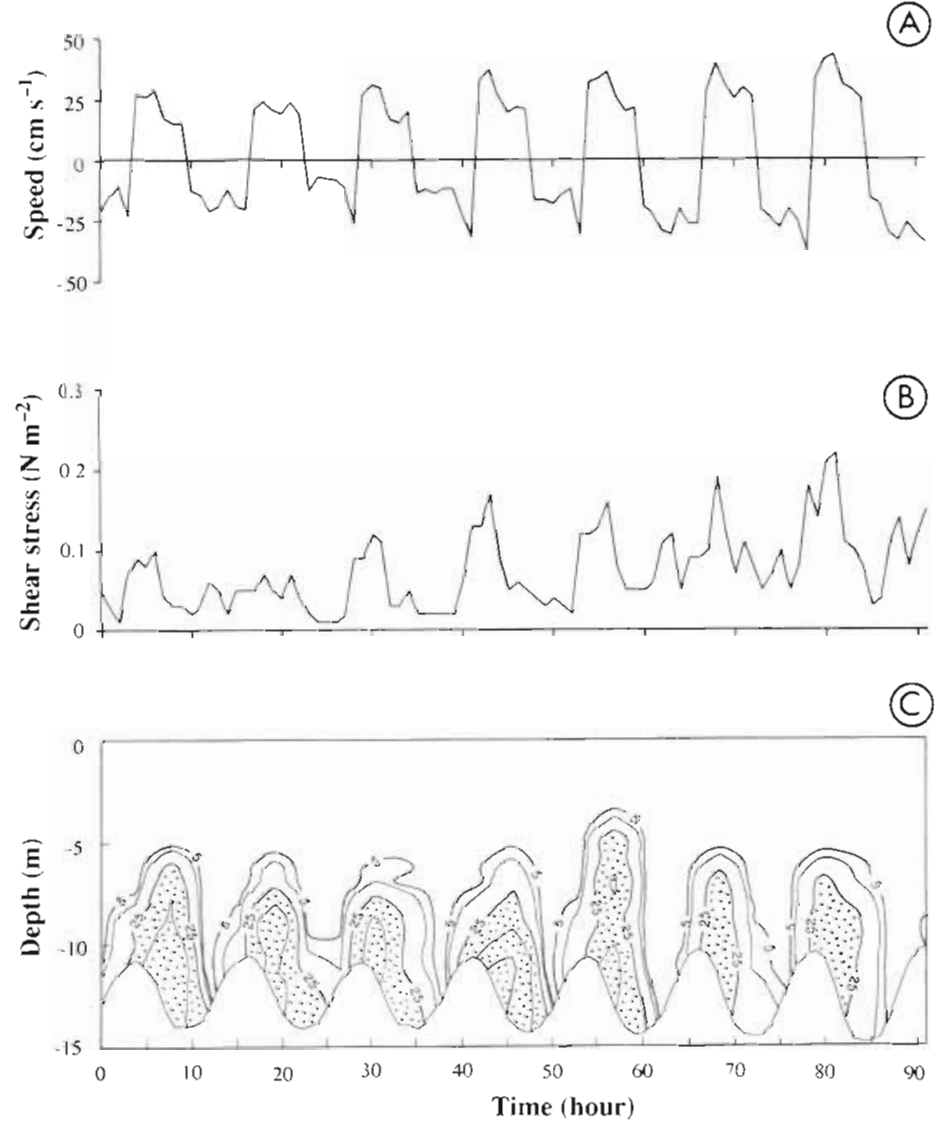

Flg. 3. (A) Short-term evolution of current speed in $\mathrm{cm} \mathrm{s}^{-1}$, (B) estimated bottom shear stress in $\mathrm{N} \mathrm{m}^{-2}$, and (C) postlarval Pectinaria koreni densities in ind. $\mathrm{m}^{-3}$ at $\mathrm{Stn} F$ during the second sampling period, 25-29 May 1992. Dotted area in Cindicates densities $\geq 25$ ind $\mathrm{m}^{-3}$

speeds were observed within 3 to $4 \mathrm{~h}$, at the end of the flood and the beginning of the ebb, corresponding to high tide slack water In contrast, there was no slack water at low tide. In relation to tidal current speeds, the bottom shear stress ranged from 0.016 to $0.280 \mathrm{~N}$ $\mathrm{m}^{-2}$ in May 1991 and from 0.007 to $0.225 \mathrm{~N} \mathrm{~m}^{-2}$ in May 1992 (Figs. 2 \& 3). Thus, maximum shear stress was observed at the beginning of the flood (i.e. within 1 to
(C)

2 h after low tide) while minimum shear stress was observed during the high tide slack water.

In May 1991, because the tidal-height amplitude increased only from 4.10 to $5.20 \mathrm{~m}$, maximum current speeds and bottom shear stress during each tidal cycle remained roughly constant during the whole sampling period. Conversely, in May 1992, in response to an increase of tidal range from 3.65 to $5.45 \mathrm{~m}$, maximum current speeds fluctuated from $24 \mathrm{~cm} \mathrm{~s}^{-1}$ at the beginning of the sampling period to $43 \mathrm{~cm} \mathrm{~s}^{-1}$ at the end of the sampling period. During the same time, the maximum bottom shear stress increased from 0.072 to $0.225 \mathrm{~N} \mathrm{~m}^{-2}$

\section{Short-term variations of postlarval abundance}

Drifting Pectinaria koreni aulophores collected during this study had only 1 to 3 ropes of sand grains attached at the anterior part of their membraneous tube and could be defined as recently settled postlarvae (i.e. less than $1 \mathrm{wk}$ (Lambert et al. 1996). Their densities fluctuated between 0 and 800 ind. $\mathrm{m}^{-3}$ in 1991 and between 0 and 143 ind. $\mathrm{m}^{-3}$ in 1992 in relation to the tidal cycle (Fi.gs. $2 \& 3$ ). In both years, postlarvae were significantly more abundant during the flood than the ebb (Table 1). In contrast, there was no significant effect of the diel cycle on abundance of resuspended postlarvae (Table 1). Maximum densities (i.e. $\geq 100$ ind. $\mathrm{m}^{-3}$ in 1991 and $\geq 25$ ind. $\mathrm{m}^{-3}$ in 1992) were consistently observed at the end of the ebb and during the flood (Figs. $2 \& 3$ ). Except during the first $20 \mathrm{~h}$ of the sampling period in 1992, such densities were only reached when the bottom shear stress exceeded a threshold value of about $0.1 \mathrm{~N} \mathrm{~m}^{-2}$.

Although some individuals were sampled in the upper part of the water column, highest postlarval

Table 1. Pectinaria koren. Depth-averaged abundance (with SD in parentheses) of postlarvae (ind. $\mathrm{m}^{-2}$ ) in relation to tide phase and time of day for both sampling periods. Differences in abundance were determined by the Mann-Whitney $U$-test at $\alpha=0.05$. $\mathrm{n}=$ number of observations

\begin{tabular}{|c|c|c|c|c|c|c|}
\hline \multirow{2}{*}{ Year } & & \multirow{2}{*}{$\begin{array}{l}\text { Tide phase } \\
\text { Ebb (E) }\end{array}$} & \multirow[b]{2}{*}{$\begin{array}{c}\text { Mann-Whitney } \\
U \text {-test }\end{array}$} & & \multirow{2}{*}{$\begin{array}{l}\text { - Time of day } \\
\text { Night }(N)\end{array}$} & \multirow[b]{2}{*}{$\begin{array}{c}\text { Mann-Whitney } \\
U \text {-test }\end{array}$} \\
\hline & Flood $(F)$ & & & $\operatorname{Day}(\mathrm{D})$ & & \\
\hline 1991 & $\begin{array}{c}1126.8(933.1) \\
n=53\end{array}$ & $\begin{array}{c}121.6(141.7) \\
n=40\end{array}$ & $\begin{array}{c}F>E \\
(p<0.001)\end{array}$ & $\begin{array}{c}612.1(752.9) \\
n=57\end{array}$ & $\begin{array}{c}462.0(858.3) \\
n=36\end{array}$ & $\begin{array}{c}D=N \\
(p=0.088)\end{array}$ \\
\hline 1992 & $\begin{array}{c}231.1(151.2) \\
n=50\end{array}$ & $\begin{array}{c}10.6(16.5) \\
n=42\end{array}$ & $\begin{array}{c}F>E \\
(p<0.001)\end{array}$ & $\begin{array}{c}104.7(148.3) \\
n=56\end{array}$ & $\begin{array}{c}121.5(155.3) \\
n=36\end{array}$ & $\begin{array}{c}D=N \\
(p=0.386)\end{array}$ \\
\hline
\end{tabular}



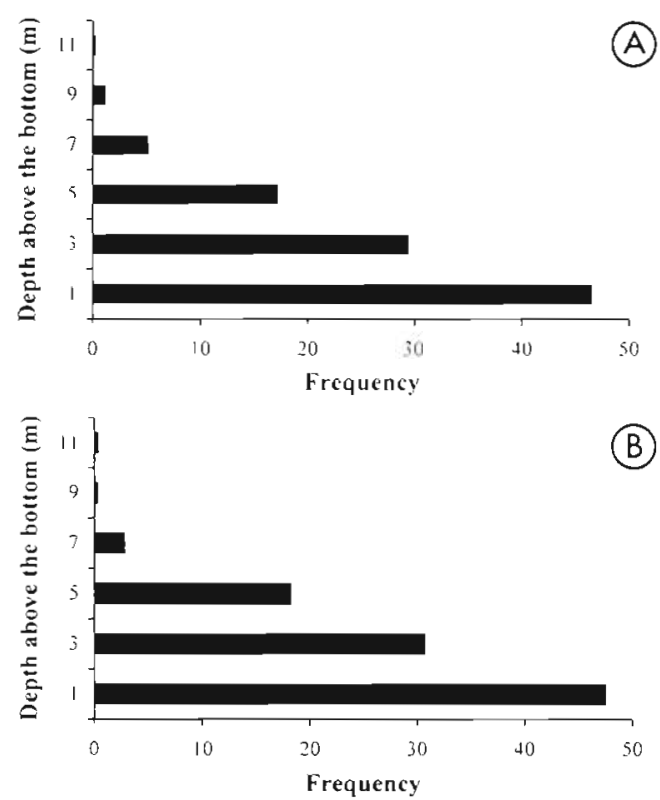

Fig. 4. Pectinaria koreni. Frequency $(\%)$ of the average vertical distribution of postlarvae for (A) 23-27 May 1991 and (B) 25-29 May 1992

densities were always observed close to the bottom (Fig. 4) About 45 and $30 \%$ of postlarvae were collected at 1 and $3 \mathrm{~m}$ above the bottom respectively. Less than $10 \%$ of the postlarval population was located at $>5 \mathrm{~m}$ above the sea bed

For both years, autocorrelation functions of depthaveraged postlarval abundance showed that decorrelation occurred at $3 \mathrm{~h}$ lag, and significant correlations reappeared after 12 to $13 \mathrm{~h}$ and $25 \mathrm{~h}$ lags (Fig. 5). They confirmed the semi-diurnal tidal periodicity of postlarval dispersal. Cross-correlation functions between depth-averaged postlarval abundance and bottom shear stress revealed that the temporal evolution of the 2 variables was not in phase (Fig. 6). Maximum positive correlation occurred when the time series of bottom shear stress was lagged backward by $2 \mathrm{~h}$. This indicates that increases in bottom shear stress preceded increases in postlarval abundance. Therefore, the maximum dispersal of Pectinaria koreni aulophores was generated 1 or $2 \mathrm{~h}$ after the maximum bottom shear stress, i.e. 3 to 4 h after low tide.

While the maximum bottom shear stress during each tidal cycle remained constant in May 1991 or strongly increased in May 1992, the densities of drifting postlarvae tended to decrease with time during both sampling periods (Figs. 2 \& 3). Thus, the depth-averaged postlarval densities during the flood period decreased from 1090 to 720 ind. $\mathrm{m}^{-2}$ in 1991 and from 280 to 200 ind. $\mathrm{m}^{-2}$ in 1992. Several mechanisms independent of the hydrodynamic regime may be proposed to explain this result: (1) the high mortality rate of marine inverte-
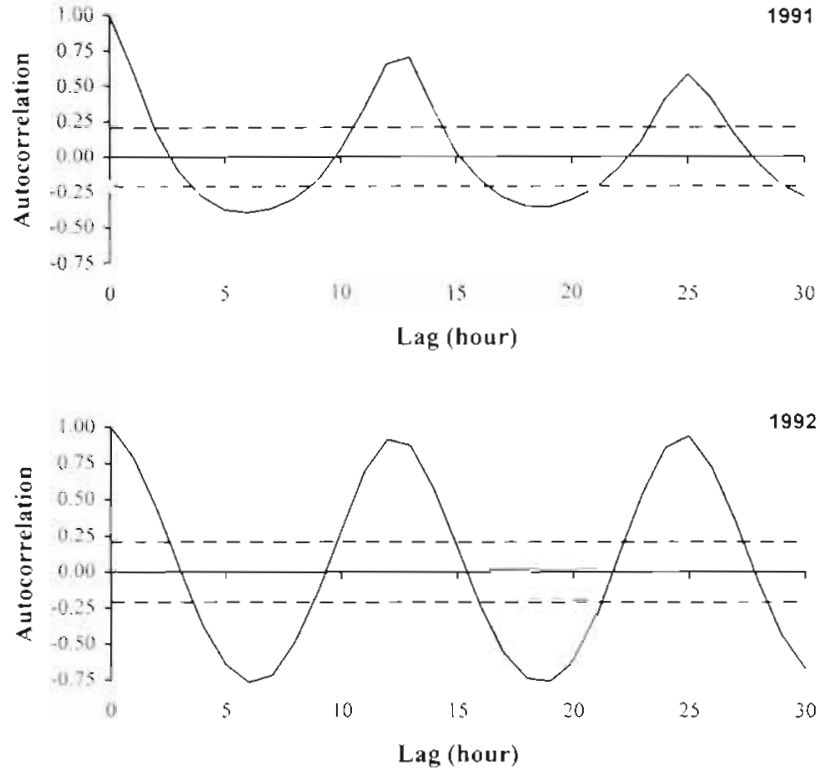

Fig. 5. Pectinaria koreni. Auto-correlation functions of depthaveraged postlarval densities (ind $\mathrm{m}^{-2}$ ) for the sampling periods in May 1991 and May 1992. Dashed lines indicate $95 \%$ confidence intervals

brate settlers just after the metamorphosis (Bachelet 1990), (2) a definitive settlement of postlarvae and (3) an accumulation of postlarvae downstream of the sampled area.
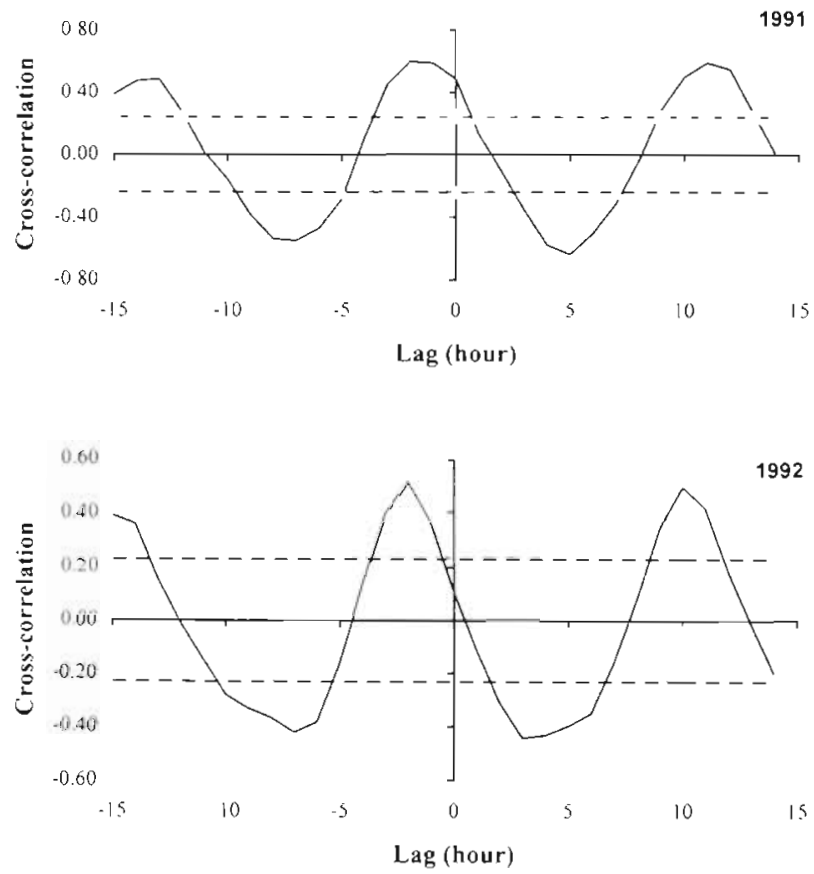

Fig. 6. Pectinaria koreni. Cross-correlation functions of depthaveraged postlarval densities (ind $\mathrm{m}^{-2}$ ) and bottom shear stress $\left(\mathrm{N} \mathrm{m}^{-2}\right)$ for the sampling periods in May 1991 and May

1992. Dashed lines indicate $95 \%$ confidence intervals 


\section{DISCUSSION}

Postlarval and juvenile transport of marine benthic invertebrates results from either passive resuspension coupled with physical disturbances or active dispersal behaviour (Günther 1992). In Konigshafen (North Sea), some macrobenthic species, e.g. the polychaete Phyllodoce mucosa, were collected in the water column during stormy weather, indicative of passive erosion from the sediment (Armonies 1994). From flume experiments, Roegner et al. (1995) demonstrated that recently settled soft shell clams Mya arenaria were transported as bedload or suspended particles when the critical shear velocity for ripple formation was exceeded. In contrast, some factors like competitive interactions or search for food may also influence postlarval emigration. In laboratory and field experiments, Ahn et al. (1993) showed that the presence of the gem clam Gemma gemma increased significantly the emigration rates of newly settled hard clam Mercenaria mercenaria. In the Wadden Sea, Günther (1991) argued that extensive dispersal of Macoma balthica juveniles from the lower parts of tidal flats to the upper parts resulted from changes in the availability of food after settlement.

In flume experiments, Lambert (1991) and Olivier et al. (in press) have revealed that Pectinaria koreni postlarvae and juveniles may react to unsuitable substratum or high densities of conspecific adults and be transported downward. Juveniles secrete a long mucous thread, up to $25 \mathrm{~cm}$, which increases the hydrodynamic drag on the organisms and enables them to leave the bottom. They are carried along the sediment surface for a few tens of centimetres and then resuspended in the water column. P. koreni juveniles participate actively in releasing themselves from the substratum before being drifted passively by currents for few minutes. The presence of a mucous thread probably reduces the sinking rate of aulophores. Thus, the mechanism of drifting is very similar to that of byssus-drifting postlarval molluscs (Sigurdsson et al. 1976, Martel \& Chia 1991).

In the field, densities of thread-drifting Pectinaria koreni postlarvae reached a maximum value of 3770 ind. $\mathrm{m}^{-2}$ in 1991 and 560 ind. $\mathrm{m}^{-2}$ in 1992. The differences from one year to another were probably due to differences in current velocities as well as differences in settler abundances. Maximum densities of benthic postlarvae varied in 1987 between 11300 and 28400 ind. $\mathrm{m}^{-2}$ amidst the muddy fine sand community (Lambert 1991), and one can assume that at least a few percent of the total $P$, koreni postlarval population were in suspension at a given point during one tidal cycle. Thus, the transport of postlarvae in the water column may represent a significant dispersal mechanism for the postlarval population and play a major role in the recruitment of this species by substantially changing the primary settlement pattern. This process is all the more important because postlarvae and juveniles retain the ability to be transported by thread-drifting for a long time. While the postlarvae collected during this study were about 1 wk old, Olivier et al. (in press) observed the resuspension of $\sim 2$ mo old juveniles in the same area in June 1992.

Numbers of drifting Pectinaria koreni aulophores collected during this study varied strongly with the state of the tide. In contrast to data obtained for several mollusc species, e.g. the floating mud snail Hydrobia ulvae or the cockle Cerastoderma edule (Armonies 1992), no diurnal rhythm of migratory activity was observed. Maximum numbers were caught during the flood (i.e. 3 to $4 \mathrm{~h}$ after low tide), closer to the maxima of current speed and bottom shear stress. At low current speeds, numbers of aulophores decreased sharply as would be expected for thread-drifting organisms. Although byssus-drift depends on both active behaviour (i.e. the secretion of a mucous thread) and water currents, $P$. koreni postlarval transport appeared to be mainly passive and controlled by hydrodynamical processes so that a bottom shear stress threshold (i.e. $0.1 \mathrm{~N} \mathrm{~m}^{-2}$ ) was required to induce it. The lag of $2 \mathrm{~h}$ between the maxima of the bottom shear stress and the densities of drifted aulophores may be explained by a skew in the calculation of the friction velocity $(u \cdot)$ due to tidal accelerative effects and/or turbulent drag modifications in an oscillating flow just after slack water (M. Belorgey pers. comm.). Palmer \& Gust (1985) suggested that the von Karman-Prandtl equation to determine $u \cdot$ is limited for field flows.

According to the hydrodynamic characteristics of the eastern part of the Bay of Seine, the relationship between the Pectinaria koreni postlarval resuspension and the tide would generate a net landward transport. Such a dominant role of tidal currents in postlarval dispersal has been seldom reported from field studies. In a turbulent tidal creek of the North Inlet Estuary (South Carolina), the abundance of resuspended bivalve juveniles (mainly Tellina sp. and Mulinia sp.) varied significantly over a tidal cycle, with a maximum during flood and ebb tides and a minimum during slack water (Palmer \& Gust 1985). In the Wadden Sea, Beukema \& de Vlas (1989) reported that the dispersal of byssus-drifting Macoma balthica juveniles was highly dependent on current speeds. Their densities were consistently higher during ebb tides than during flood tides, resulting in a net seaward transport from the Wadden Sea to the North Sea. In the Bay of Seine, Olivier et al. (in press) pointed out that the dispersal of juveniles of some dominant macrozoobenthic species (i.e. the bivalves Abra alba, Cultellus pellucidus and 
Tellina fabula and the polychaete $P$. koreni) could be partly related to tidal currents.

Even if the semi-diurnal tidal currents constitute the major component of the instantaneous circulation in the eastern part of the Bay of Seine, the dispersal of invertebrate postlarvae and juveniles could also be affected by other hydrodynamic processes, like those generated by wind conditions. Thus, wind influences the general circulation by changing the direction and the velocities of tidal currents and by creating waves (Armonies 1994). On 2 intertidal sandflats in Nova Scotia (Canada), the passive bedload transport of the softshell clam Mya arenaria is mainly controlled by wind velocity (Emerson \& Grant 1991). In the Wadden Sea, weather conditions alter the migratory activity of drifting juvenile molluscs (Armonies 1992). During our study, sampling was carried out during calm weather conditions (mean wind velocity of $3.7 \mathrm{~m} \mathrm{~s}^{-1}$ in 1991 and $4.1 \mathrm{~m} \mathrm{~s}^{-1}$ in 1992) and no wind effect could be detected. Nevertheless, in the same area in June 1992, Olivier et al. (in press) showed that swell produced by moderate winds $\left(6\right.$ to $7 \mathrm{~m} \mathrm{~s}^{-1}$ ) could be sufficient to increase significantly the bottom shear stress $\left(>0.15 \mathrm{~N} \mathrm{~m}^{-2}\right.$ ) and induce a permanent resuspension of Pectinaria koreni postlarvae, independently of the tidal cycle. The relative effect of tide and swell should strongly affect the influence of postlarval dispersal on the recruitment of $p$. koreni. While the tide favours a regular and landward transport during the flood, the swell generates an episodic transport which sometimes strengthens or sometimes is opposed to the tidal effect.

In a recent review on dispersal of intertidal macroinvertebrates, Günther (1992) argued that transport of postlarvae and juveniles can be regarded as mesoscale dispersal, ranging from meters to kilometers. This spatial scale is related to temporal scales of hours to seasons (Armonies 1994). In flume experiments, Lambert (1991) showed that the downstream advection distance for a single resuspension event of a Pectinaria koreni juvenile (ca 3 to $5 \mathrm{~mm}$ ) varied on average between 25 and $40 \mathrm{~m}$ and occasionally reached $65 \mathrm{~m}$ at a current velocity of $20 \mathrm{~cm} \mathrm{~s}^{-1}$. By simulating tidal currents in a recirculating flume, Roegner et al. (1995) estimated transport distances of 10 to $10^{2} \mathrm{~m}$ for the soft-shell clam Mya arenaria by repeated resuspension events over a tidal period. During winter (ca $3 \mathrm{mo}$ ), juveniles of the bivalve Macoma balthica were tidally transported from tidal flats of the Wadden Sea to subtidal areas of the North Sea over distances of several kilometers or even some tens of kilometers (Beukema \& de Vlas 1989). In the Wadden Sea, a similar migration by passive tidal transport over distances of some kilometers was also reported during the autumn-winter season for the lugworm Arenicola marina (Beukema \& de Vlas 1979).
In terms of population dynamics, the net landward transport of drifting Pectinaria koreni aulophores generated by tidal currents could counteract the effects of larval dispersal. This transport could act as a feed-back mechanism which contributes to the return of numerous individuals that had settled offshore on unfavourable, coarse sediment to favourable coastal sites and could also favour the accumulation of recruits in low-energy areas. In a macrotidal environment like the Bay of Seine, this mechanism may be one important process which explains the spatio-temporal stability of the P. koreni adult population observed between 1986 and 1991 seaward of the Seine estuary and off Deauville (Thiébaut 1994). Likewise, Beukema (1993) and Flach \& Beukema (1994) argued that the stability of Arenicola marina and Macoma balthica populations on tidal flats of the Wadden Sea, in comparison with the other dominant macrozoobenthic species, resulted partly as a consequence of the juvenile migrations exhibited by both these species.

Acknowledgements. This study was carried out under the GDR Manche program. It was a part of the French National Program on Recruitment supported by the CNRS and IFREMER. We are grateful to the crew of 'NO Pluteus II', C. Conq, D. Bernardo, J. C. Lorgere and F. Olivier for their valuable assistance at sea, and P. Guyard (University of Southampton) for the English proof reading.

\section{LITERATURE CITED}

Ahn LH, Lopez G, Molouf R (1993) Effects of the gem clam Gemma gemma on the early post-settlement emigration, growth and survival of the hard clam Mercenaria mercenaria. Mar Ecol Prog Ser 99:61-70

Armonies W (1992) Migratory rhythms of drifting juvenile molluscs in tidal waters of the Wadden Sea. Mar Ecol Prog Ser 83:197-206

Armonies W (1994) Driftıng meio- and macrobenthic invertebrates on tidal flats in Königshafen: a review. Helgol Meeresunters 48:299-320

Armonies W, Hellwig-Armonies M (1992) Passive settlement of Macoma balthica spat on tidal flats of the Wadden Sea, and its implications in distribution patterns. Neth J Sea Res 29:371-378

Auffret JP, d'Ozouville L (1986) Apports de l'imagerie fournie par le sonar à balayage latéral à la connaissance de la dynamique sédimentaire en Baie de Seine. Actes Colloq IFREMER 4:201-210

Bachelet G (1990) Recruitment of soft-sediment infaunal invertebrates: the importance of juvenile benthic stages. La Mer 28:199-210

Beukema JJ (1993) Successive changes in distribution patterns as an adaptative strategy in the bivalve Macoma balthica (L.) in the Wadden Sea. Helgol Meeresunters 47:287-304

Beukema JJ, de Vlas J (1979) Population parameters of the lugworm, Arenicola marina, living on tidal flats in the Dutch Wadden Sea. Neth J Sea Res 13:331-353

Beukema JJ, de Vlas J (1989) Tidal-current transport of thread drifting postlarval juveniles of the buvalve Macoma 
balthica from the Wadden Sea to the North Sea. Mar Ecol Prog Ser 52:193-200

Butman CA (1987) Larval settlement of soft sediment invertebrates: the spatial scales of pattern explained by active habitat selection and the emerging role of hydrodynamical processes. Oceanogr Mar Biol A Rev 25:113-165

Cabioch L, Gentil F (1975) Distribution des peuplements benthiques dans la partie orientale de la Baie de Seine. C R Acad Sci Paris 208D:571-574

Chabert d'Hières G (1986) La circulation des eaux en Baie de Seine. Actes Colloq IFREMER 4:15-24

Emerson CW, Grant J (1991) The control of soft-shell clam (Mya arenaria) recruitment on intertidal sand flats by bedload sediment transport. Limnol Oceanogr 36:1288-1300

Flach EC, Beukema JJ (1994) Density-governing mechanisms in populations of the lugworm Arenicola marina on tidal flats. Mar Ecol Prog Ser 115:139-149

Gentil F, Irlinger JP, Elkaïm B, Proniewski F (1986) Premières données sur la dynamique du peuplement macrobenthique des sables fins envasés à Abra alba de la Baie de Seine orientale. Actes Colloq IFREMER 4:409-419

Gross TF, Nowell ARM (1983) Mean flow and turbulence scaling in a tidal boundary layer. Cont Shelf Res 23:109-126

Günther CP (1991) Settlement of Macoma balthica on an intertidal sandflat in the Wadden Sea. Mar Ecol Prog Ser $76: 73-79$

Günther CP (1992) Dispersal of intertidal invertebrates: a strategy to react to disturbances at different scales? Neth $J$ Sea Res 30:45-56

Irlinger JP, Gentil F, Elkaim B (1991) Reproductive biology of the polychaete Pectinaria koreni (Malmgren) in the Bay of Seine (English Channel). Ophelia Suppl 5:343-350

Lagadeuc Y (1992) Transport larvaire en Manche, exemple de Pectinaria koreni en Baie de Seine. Oceanol Acta 15: 383-395

Lagadeuc Y, Retière C (1993) Critères d'identification rapide des stades de développement des larves de Pectinaria koreni (Malmgren) (Annélide Polychète) de la Baie de Seine (Manche). Vie Milieu 43:217-224

Lambert R (1991) Recrutement d'espèces benthiques à larves pélagiques en régime mégatidal. Cas de Pectinaria koreni (Malmgren), annélide polychète. Thèse de doctorat, Université de Rennes I

Lambert R, Retière C, Lagadeuc Y (1996) Metamorphosis of Pectinaria koreni (Annelida: Polychaeta) and recruitment

This article was submitted to the editor of an isolated population in the English Channel. J Mar Biol Ass UK 76:23-36

Legendre L, Legendre P (1984) Ecologie numérique. 2. La structure des données écologiques, 2ème édn. Masson, Paris

Le Hir P, L'Yavanc J (1986) Observations de courant en Baie de Seine. Actes Collog IFREMER 4:25-34

Martel A, Chia FS (1991) Foot-raising behaviour and active participation during the initial phase of post-metamorphic drifting in the gastropod Lacuna spp. Mar Ecol Prog Ser $72: 247-254$

Olivier F, Desroy N, Retière C (in press) Habitat selection and adult recruit interactions in Pectimaria koreni (Malmgren) (Annelida: Polychaeta) post-larval populations: results of flume experiments. J Sea Res

Olivier F, Vallet C, Dauvin JC, Retière C (in press) Depositionresuspension mechanisms involved in post-larval and juvenile population dynamics in the Abra alba community of the eastern part of the Bay of Seine (English Channel). $J$ Exp Mar Biol Ecol

Palmer MA, Gust G (1985) Dispersal of meiofauna in a turbuJent tidal creek. J Mar Res 43:179-210

Roegner C, André C, Lindegarth M, Eckman JE, Grant J (1995) Transport of recently settled soft-shell clams (Mya arenaria L.) in laboratory flume flow. J Exp Mar Biol Ecol 187:13-26

Scheltema RS (1986) On dispersal and planktonic larvae of benthic invertebrates: an eclectic overview and summary of problems. Bull Mar Sci 39:290-322

Scherrer B (1984) Biostatistique. Gaetan Morin, Paris

Sigurdsson JB, Titman CW, Davies PA (1976) The dispersal of young postlarval bivalve molluses by byssus threads Nature 262:386-387

Thiébaut E (1994) Dynamique du recrutement et dispersion larvaire de deux annélides polychètes, Owenia fusiformis et Pectinaria koreni, en régime mégatidal (Baie de Seine orientale, Manche). Thèse de doctorat, Université de Paris VI

Thiébaut E, Dauvin JC, Lagadeuc Y (1992) Transport of Owenia fusiformis larvae (Annelida: Polychaeta) in the Bay of Seine. I. Vertical distribution in relation to water column stratification and ontogenic vertical migration. Mar Ecol Prog Ser 80:29-39

Van Rijn LC (1982) Equivalent roughness of alluvial bed J Hydraul Div, Am Soc Civ Engrs 108:1215-1218

Manuscript first received: December 29, 1995

Revised version accepted: April 3,1996 